\title{
高放射線環境用ゴム材料の開発
}

\author{
中務 定義，煙崎 岳，吉田 暁弘，門脇 良人
}

\section{Development of Rubber Material for High Radiation Field}

\begin{abstract}
Sadayoshi NAKATSUKASA, Takeshi TABASAKI, Akihiro YOSHIDA and Yoshito KADOWAKI (HAYAKAWA RUBBER CO., LTD., 5351 Minamigaoka, Minoshima-cho, Fukuyama-shi, Hiroshima 721-8540, Japan)
\end{abstract}

Generally flexible polymeric materials exposed to radiation can't be used because they soften or harden remarkably in high radiation environment. Aromatic polymers such as PEEK, PI, and PES are also known as radiation-proof polymeric materials. Aromatic polymers are very hard, they can't be used for products like a packing where flexibility is required. We developed a new vulcanized rubber compound by the use of various additives and polymer blend. This developed rubber compound has a high radiation-proof performance by reaction balance of cross-linking and decomposition in this rubber. This rubber compound has a rubber elasticity even if exposed to radiation of MGy level, and its radiation proof is more than 5 times as high as conventional polymeric materials. This rubber compound is much more flexible than the aromatic polymers which are the used as conventional radiation-proof polymers.

Key Words : Radiation, Radiation-resistivity, Radiation-deterioration, Polymer, Radioprotector

1. は じ め に

先日シネマコンプレックスで皆さんよくご存知の SF 映 画を鑑賞した。時は 23 世紀半ば，人類は宇宙へと旅立ち 他の惑星と旨く共存している．子供の頃より見慣れた物語 であり，超光速飛行，人体の瞬間移動などの場面を楽しん でいた。ところが終盤になり驚くべきシーンが登場した。 なんと宇宙船の動力源室（今で言うところのエンジンルー ム）は平常時でも高濃度の放射線で満たされているという 設定ではないか。 そこで瞬時に技術屋になった自分が出現 した。興味がストーリーから乘離し，燃料元素の推測に走 ってしまった.ウランかプルトニウムか MOX 燃料か，は たまた核爆弾と疎遠なトリウムなのか，この時代ならば核 融合なのか.いや後 200 年以上経過すれば未だ人類が発見 していない新元素なのか，ならば原子番号は何番なのだろ うか. いずれにしても長期間の運行が, エネルギー補給無 しに可能なものは他に無いという事であろうと想像は膨ら むばかりだった，そこでの個人的結論は，人類は暫く“放 射線”と旨く程よい関係を保っていかなければならないと いう事だと感じた。

さて従来ゴムが劣化する外的要因として，いくつものも のが想定され，検討されてきた歴史がある。それは，熱， オゾン, 紫外線, 各種接触物質, 電気あげていけば枚挙に 暇は無い、日本ゴム協会においても最も古い分科会は“環
境劣化分科会”であることからも，ゴムの使用に際して， 寿命予測の観点からも劣化の問題は非常に重要なテーマで あると皆が認識している。ここで福島の事故以来新たに放 射線劣化という概念が再注目されてきた。尚且つ, 従来の 放射線劣化の検討レベルを遥かに超えた高濃度放射線下で の劣化である，本レポートではゴム業界では馴染みの薄い 放射線の特性と高分子の劣化について報告したい。

\section{2. 最近のトピックス}

ここ 2 年半の間に, 新聞等で取り上げられた出来事は次 のようなものがあげられる.

*再稼動していた大飯原子力発電所 4 号機が定期検査のた め平成 25 年 9 月 15 日午後 11 時運転を停止した。これに より国内の全ての原子力発電所は再びゼロ稼動状態とな り, 事故以前には30\%以上依存していた原子力発電所 からの電力の供給は完全にストップした。

*事故当時は余り議論されていなかった PWR（加圧水型） と BWR（沸騰水型）の発電方式による安全性の比較議 論がされるようになった。

*地下水の流出を食い止める事が出来ず，またストロンチ ウムの除去装置は停止したままの状態である. しかし再 稼動となればセシウム，ストロンチウムなどの約 60 種 類の放射性物質の除去の問題がある.

*事故当時は議論されていなかったトリチウムによる污染 
が大きな問題となっているが，水素の同位体であるトリ チウムを除去する方法は全く無いといっても過言ではな く，法的改正，地域住民の同意がなされなければ海水へ の放出は出来ない状態にある.

*がんが増えるとされる $100 \mathrm{mSv}$ 以上の甲状腺被曝をし た作業員が推計も含め 2 千人いたことが分かり，平成 24 年 12 月の公表人数より 10 倍以上増えた。また中には 11,800 mSv被曝している人もいることも公表された.

現時点では核分裂反応の安全確保の三原則である核分裂 反応の「停止」，燃料の「冷却」までは完了したと言える かもしれないが，放射能の「閉じ达め」は完全に失敗して いる状態にある。

\section{3. 放射線の基礎知識}

\section{1 放射線}

“放射線”は放射性物質から放出される粒子線あるいは 電磁波のことである．また，放射線を出す能力を “放射能”， 放射線を出す物質を “放射性物質”という。電灯に例える ならば，放射線とは電灯が発する光であり，放射能とは電 灯の発光源が単位時間当たりに光を出せる能力であり，放 射性物質とは光を発生させる電灯であるといえる.

\section{2 放射線の種類}

放射線は，高いエネルギーをもち高速で飛ぶ粒子（粒子

表 1 放射線の種類と特徵

\begin{tabular}{|c|c|l|}
\hline 種類 & 分類 & \multicolumn{1}{|c|}{ 特徵 } \\
\hline$\alpha$ 線 & 粒子線 & 高速で飛び回る He の原子核 \\
\hline$\beta$ 線 & 粒子線 & 電子の高速な流れ \\
\hline$\gamma$ 線 & 電磁線 & 紫外線, X 線と同じ電磁波 \\
\hline 中性子線 & 粒子線 & 原子核を構成する中性子の流れ \\
\hline
\end{tabular}

表2 代表的な放射性元素

\begin{tabular}{|c|l|c|c|}
\hline & \multicolumn{1}{|c|}{ 元素名 } & 半減期 & 主な放射線種 \\
\hline \multirow{5}{*}{ 天然放射性核種 } & ウラン 238 & 44.8 億年 & $\alpha$ 線 \\
\cline { 2 - 4 } & トリウム 232 & 141 億年 & $\alpha$ 線 \\
\cline { 2 - 4 } & ラジウム 226 & 1,600 年 & $\alpha$ 線 \\
\cline { 2 - 4 } & カリウム 40 & 12.8 億年 & $\beta$ 線, $\gamma$ 線 \\
\cline { 2 - 4 } & トリチウム 3 & 12.3 年 & $\beta$ 線 \\
\cline { 2 - 4 } & 炭素 14 & 5,730 年 & $\beta$ 線 \\
\hline \multirow{5}{*}{ 人工放射性核種 } & プルトニウム 239 & 2.41 万年 & $\alpha$ 線 \\
\cline { 2 - 4 } & ヨウ素 131 & 8 日 & $\beta$ 線, $\gamma$ 線 \\
\cline { 2 - 4 } & セシウム 137 & 30.1 年 & $\beta$ 線, $\gamma$ 線 \\
\cline { 2 - 4 } & ストロンチウム 90 & 29.1 年 & $\beta$ 線 \\
\hline
\end{tabular}

線) と，高いエネルギーをもつ短い波長の電磁波の総称で あり，代表的な放射線としては $\alpha$ 線， $\beta$ 線， $\gamma$ 線，中性子 線が挙げられる(表1).

\section{3 主な放射性元素}

放射性元素とは放射能をもつ元素のことであり，自然界 に存在する天然放射性元素と，原子力施設や核実験に由来 する人工放射性元素に分類できる，代表的な放射性元素を

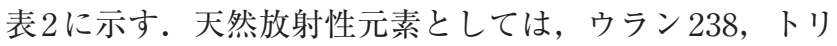
ウム 232 , カリウム 40 などがあり，これらは約 46 億年前 に地球ができたときから存在している. 人工放射性元素と しては，ウラン 235, プルトニウム 239, ヨウ素131, セシ ウム 137 ，ストロンチウム 90 などがある．ウラン $235 ，$ プ ルトニウム 239 は核兵器や原子力施設で利用され，ヨウ素 131, セシウム 137 , ストロンチウム 90 は原子力発電所で の生成量が多く，福島の事故ではこれらの放射性物質が大 気中に大量に放出された。

\section{4 放射線の単位}

放射線に関する様々な単位が存在するがその中で代表的 なものを紹介する（表3）。

放射線量（Bq，ベクレル）は放射性物質の放射線を放 出する能力を表した数值, すなわち放射能のことである. 放射性物質ごとに放出する放射線種, 放射線の持つエネル ギー量は異なるが, 放射線量にはその要素は反映されない。 その為, 放射線から受けるエネルギー量を表した吸収線量 （Gy，グレイ）と放射線量の関係は放射性物質ごとに全く 異なるといえる．また，放射線種による人体への影響は異 なり，線質係数として表される（表 4$)$ ．放射線の人体へ の影響を表した線量当量（Sv，シーベルト）とは吸収線 量に線質係数を乗じたものである.

\section{4. 放射線による高分子の劣化メカニズム}

物質中を放射線が通過すると, 物質が粒子線や電磁波の エネルギーを吸収するため，放射線は徐々にではあるがエ ネルギーを失う。エネルギーを吸収した物質の内部では,

表4 各放射線種の線質係数

\begin{tabular}{|c|c|c|c|c|c|}
\hline 放射線種 & $\alpha$ 線 & $\beta$ 線 & $\gamma$ 線 & 中性子線 & 陽子 \\
\hline 線質係数 & 20 & 1 & 1 & 10 & $5 \sim 20$ \\
\hline
\end{tabular}

表3 放射線の単位と定義

\begin{tabular}{|c|c|c|}
\hline 名称 & 単位 & 定義 \\
\hline 放射線量 & $\mathrm{Bq}$ (ベクレル) & $\begin{array}{l}1 \text { 秒間に何個の放射線が放出されるかを表した数值 } \\
\cdot \text { 放射線の種類やエネルギー量には関係しない }\end{array}$ \\
\hline 吸収線量 & Gy（グレイ） & 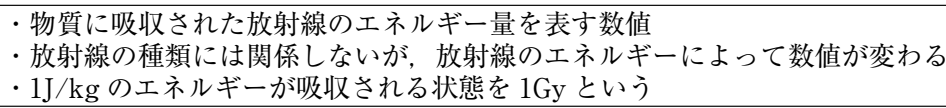 \\
\hline 線量当量 & Sv（シーベルト） & $\begin{array}{l}\cdot \text { 放射線の人体への影響を表す数值 } \\
\cdot \text { 放射線の種類, エネルギー量によって数值が変わる } \\
\text { •線量当量 }(\mathrm{Sv})=\text { 線質係数 } \times \text { 吸収線量 }(\mathrm{Gy})\end{array}$ \\
\hline
\end{tabular}




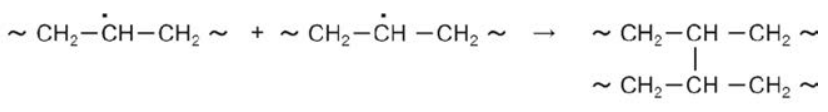

$\sim \mathrm{CH}_{2}-\dot{\mathrm{CH}_{2}}+\mathrm{CH}_{2}=\mathrm{CH} \sim \rightarrow \sim \mathrm{CH}_{2}-\mathrm{CH}_{2}-\dot{\mathrm{CH}}-\mathrm{CH}_{2} \sim$

図 1 高分子の放射線照射による高分子化機構

$\sim \mathrm{CH}_{2}-\dot{\mathrm{CH}_{2}}+\dot{\mathrm{C}} \mathrm{H}_{2}-\mathrm{CH}_{2}-\mathrm{CH}_{2} \sim \rightarrow \sim \mathrm{CH}_{2}-\mathrm{CH}_{3}+\mathrm{CH}_{2}=\mathrm{CH}-\mathrm{CH}_{2} \sim$

図2 高分子の放射線照射による低分子化機構

化学反応の引き金となる反応活性種であるイオンやラジカ ルが生じる. $\alpha$ 線のような荷電粒子, $\beta$ 線と $\gamma$ 線, 中性子 では有機物中でのエネルギー付与の仕方が違うが，結果と してイオンやラジカルを生成させることに変わりはない. 高分子における放射線照射の場合，物質内部で発生したラ ジカルにより高分子化と低分子化が平行して起こり，高分 子化が先行して起こる架橋型と低分子化が先行して起こる 崩壊型に分類することができる．放射線照射による高分子 材料の高分子化機構および低分子化機構を図 1,2 に示す. 一般にC-C 結合の場合を例にとると，ヴィニル型は架橋型 であり，ヴィニリデン型は崩壊型である。架橋型ポリマー は崩壊型ポリマーに比べて放射線に対する耐性が一般的に 大きく, 適当な耐放射線性付与剂の添加により, 性能の改 善が容易にできるとされているが，従来その議論の対象は 破断強度変化が中心であった1)。しかし，これは高線量の 放射線照射後，材料表面硬度の上昇，破断時伸びの減少に ついては，良好なデータが得られず，全くといってよいほ ど効果的対策がなかったからに他ならない，結果，放射線 架橋型高分子においても放射線照射後，ゴム表面硬度は， 異常なまでに跳ね上がり，弾性体として完全に機能しなく なってくる2).

\section{5. 一般的放射線劣化試験}

高分子材料が放射線の環境下で使用される場合は，通常 低いレベルの放射線に長時間暴露される，例えば，原子炉 の格納容器内では $100 \mathrm{rad} / \mathrm{h}(1 \mathrm{~Gy} / \mathrm{h})$ 以下の線量であり, 人工衛星でも最大で， $1 \mathrm{krad} / \mathrm{h}$ といわれている。原子力 発電所で使用される電線・ケーブル材料は原子炉の通常運 転時において，線量率 $1 \mathrm{~Gy} / \mathrm{h}$ 以下，温度 $40 \sim 60{ }^{\circ} \mathrm{C}$ の環 境に長時間さらされる。このような環境下においては空気 中の酸素が高分子材料中に充分拡散できるため, 酸化劣化 が起こると考えられている．耐放射線試験をこのような低 線量下で長時間かけて行なうことは現実的でないため，通 常は線量率を高めて照射時間を短縮して行なわれている. 実際の $\gamma$ 線照射では $0.1 〜 1 \mathrm{Mrad} / \mathrm{h} （ 1 \sim 10 \mathrm{kGy} / \mathrm{h} ）$ で照 射されることが多く，これは実使用条件に比べて $10^{3}$ 〜 $10^{6}$ 倍も促進されている。これまで報告されている多くの 放射線のデー夕はこのような促進試験で得られたものが多
い. 高分子材料をはじめとする有機材料の耐放射線性およ び使用限界線量についての膨大なデータがこれまでに蓄積 されている ${ }^{3)}$.

\section{6. 高分子に対する耐放射線付与}

CREN（欧州原子核共同研究所）によりまとめられたゴ ムの一般的な耐放射線性は $1 \mathrm{MGy}$ 以上において $\mathrm{EPR}, \mathrm{U}$, SBRが優れておりフッ素, シリコーン, IIRの性能が劣る と報告されている ${ }^{1)}$. 高い耐放射線性を示す材料として, PEEK (ポリエーテルエーテルケトン) やPI（ポリイミド） などの芳香族高分子が知られているが，これらは成形性， 弾性, 可とう性, 経済性に劣るため用途・使用方法が限定 されている. $3 \mathrm{MGy}$ の照射を受けて硬度が 80 以下，引張 伸び $100 \%$ 以上の可とう性を有するゴム架橋体が見受けら れず，現実の場で使用する場合はさらに放射線に対する安 定化方法を考慮する必要がある。

高分子に耐放射線性を付与するには，それぞれの劣化原 因に対応していくこと ${ }^{4)}$ が大切である. 先にも述べたよ うにポリマーの放射線劣化は，橋架け，分解，酸化による ものであり，放射線反応の素過程を振り返ると，放射線が ポリマーと衝突した後の最初の過程, 初期過程は, ポリマ 一のイオン化と励起である. 次いで, エネルギー移動が起 こり, 励起分子からラジカルが生成する. 橋架け, 分解, 酸化などの反応は, この後, 二次過程の反応であり, ラジ カルの生成を抑制できれば，放射線劣化も制御できること になる，種類をあげれば，電子・イオン捕捉剤，エネルギ 一移動剤, ラジカル捕捉剤, 酸化防止剂, 可塑剂などがあ げられる。

実際のポリマー処方では，これらをうまく組み合わせる ことによりポリマーの耐放射線性を大幅に改善することが できる。われわれは長期間にわたりポリマーへの “耐放射 線付与”を検討し，MGyレベルの放射線領域においても ゴム弾性を保持できる組成物の開発に成功した。図 3 に開 発した耐放射線性ゴム（100G） と一般的ゴムの放射線照 射による物理強度の変化を示す，ゴム配合に耐放射線処方 を施すことで，吸収線量に対する物理強度の変化を低減で きる．また，耐放射線性ゴムとフッ素ゴムの放射線照射前
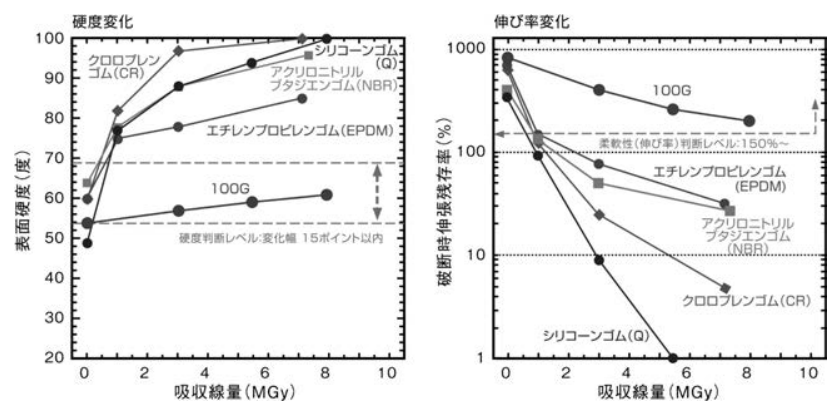

図3 ゴムの放射線照射による特性比較 


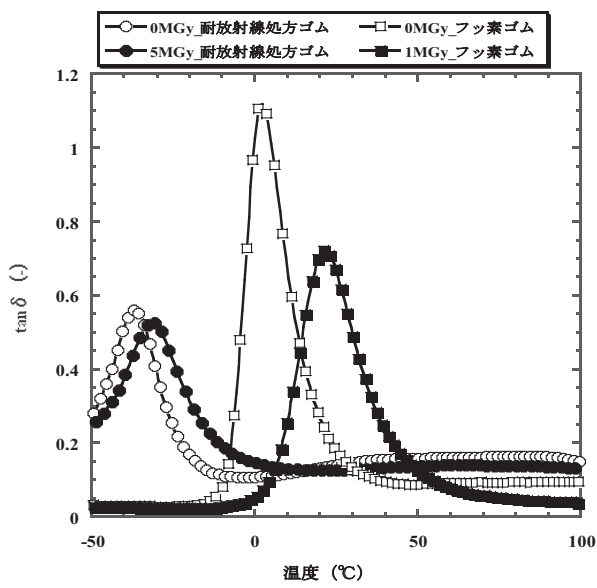

図4 放射線照射前後の耐放射線処方ゴムとフッ素ゴムの動的粘弾性 $(\tan \delta)$ 変化

後の動的粘弾性を図 4 に示す.フッ素ゴムは $1 \mathrm{MGy}$ 照射後, $\tan \delta$ のピークが高温側にシフトし，ピーク值が低下する 傾向を示した。一方で，耐放射線性ゴムはフッ素ゴムと同 様に放射線照射により $\tan \delta$ に変化が見られるが，変化量 は微小なものであった。

\section{7. ま と め}

福島第一原発事故から 2 年半経過した現在も 20 万人とも 30 万人ともいわれる人々が住居を奪われ避難している. また 2 万人近い方々が亡くなられ，行方不明となっている. 被災地から遠い人にとっては昔の話になりつつあるが，改 めて暗涙にむせぶ思いである。

科学技術の進歩は人々の暮らしを豊かにしてきたが，反 面公害問題から始まり，地球温暖化などの弊害をも生み出 してきた。今日本は放射線被害という未曾有の災害に見舞
われている。更に状況は日に日に深刻さを増してきている ようにも見えるし，その対策も場当たり的対応が感じられ る. 文明の進歩の高度化と共にやはり想定外の対策が必要 となるという事であろう。特に非常に専門的判断が迫られ る状態において，技術者のベクトルが定まらない事は致命 的であり，百家争鳴の場を設けるべきと考える。ここで持 ちこたえるのかそれともチェルノブイリの二の舞になるの か国力，人間力が試されている．新しい技術は新しいもの を生み出すが，同時に多くのリスクも生み出してしまう。 本レポートが福島の原発復旧の一助となれば幸いである.

\section{References}

1) Kusano, J.; Uno, Y.:Radiation Resistivity of Polymeric Materials with Data Tables JAERI-Data 2003-015, JAPAN ATOMIC ENERGY AGENCY Ed., JAPAN ATOMIC ENERGY AGENCY, Ibaraki, P9 (2003)

2 ) Nakatsukasa, S.: Kogyozairyo, 59, 82 (2011)

3 ) Tai Hosyasensei Yuden·Zetsuen Zairyo no Saikin no Doko ( I ), Tai Hosyasensei Yuden-Zetsuen Zairyo Tyosa Senmon Iinkai Ed., Denki Gakkai, Tokyo, Denki Gakkai Gijutsu Hokoku (part II) No.316th., p.25 (1989)

4 ) Hagiwara, M.; Oda, E.; Fujimura, S.: Gensiryoku Kogyo, Nikkan Kogyo Shinbunsya, Tokyo, 24, 49 (1978)

\section{日本語表記参考文献}

1 ）草野譲一，宇野喜智：高分子系材料の耐放射線特性とデー夕集 JAERI-DATA 2003-015, 日本原子力研究開発機構編, 日本原子 力研究開発機構, 茨城, p.9 (2003)

2 ) 中務定義：工業材料，59，82（2011）

3 ) 耐放射線性誘電・絶縁材料の最近の動向（I），耐放射線性誘 電・絶縁材料調查専門委員会編，電気学会，東京，電気学会技 術報告（II 部）第316号，p.25（1989）

4 ）萩原幸, 小田英輔, 藤村俊一：原子力工業, 日刊工業新聞社, 東京，24，49（1978）

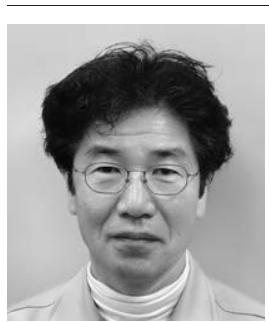

中務 定義; 早川ゴム株式会社（広島県福山 市箕島町南丘 5351 番地) 新事業開発室室長. 昭和 57 年，鳥取大学工学部工業化学科卒業。 同年，早川ゴム株式会社入社。日本ゴム協会 環境劣化研究分科会会員, 日本ゴム協会誌編 集委員

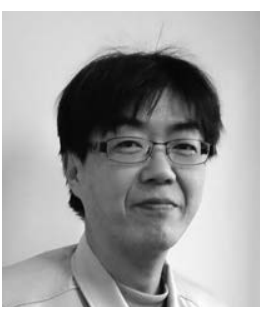

㖶崎＼cjkstart岳；早川ゴム株式会社（広島県福山市 箕島町南丘 5351 番地）技術開発グループ課長. 平成 3 年，近畿大学農学部農芸化学科卒業. 同 年，早川ゴム株式会社入社.

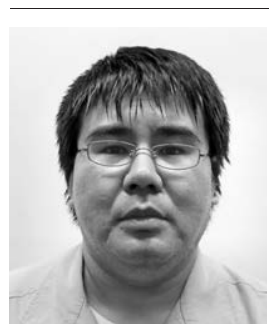

吉田＼cjkstart暁弘；早川ゴム株式会社（広島県福山 市箕島町南丘 5351 番地）技術開発グループ. 平成 21 年, 熊本大学大学院複合新領域化学専 攻修士課程修了。同年，早川ゴム株式会社入 社.

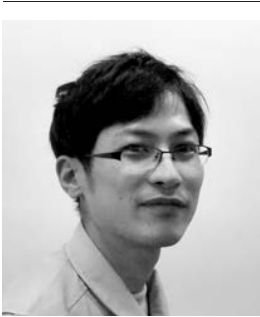

門脇 良人; 早川ゴム株式会社（広島県福山 市箕島町南丘 5351番地）技術開発グループ, 技術開発 2 チーム，主任。平成 18 年，愛媛大 学大学院理工学研究科応用化学専攻修了. 平 成 18 年，早川ゴム株式会社入社，現在に至る. 